\title{
Inquiry-based E-module for Geometry Learning Subject
}

\author{
I Ketut Suastika, Dyah Tri Wahyuningtyas"
}

University of Kanjuruhan Malang, Indonesia

Received October 10, 2019; Revised December 5, 2019; Accepted December 11, 2019

Copyright $\subseteq 2020$ by authors, all rights reserved. Authors agree that this article remains permanently open access under the terms of the Creative Commons Attribution License 4.0 International License

\begin{abstract}
The development of technology and the digital era began with the move from printed books to electronic books, so the purpose of this study was to develop an inquiry-based e-module for Geometry Learning subject in Elementary School Teacher Education Study Program. The study employed and developed Plomp research method consisting of initial investigation, prototype, and assessment. Additionally, the study focused on presenting the prototype of the inquiry-based e-module along with its validation results. In terms of data analysis techniques, this study administered that of quantitative and qualitative description. It was shown that the results of the prototype development of the inquiry-based e-module included user guidance, learning outcomes, introduction, two-dimensional figures, geometry, and evaluation. The learning materials on either two-dimensional figures or geometry were presented in the form of independent learning. The evaluation of the e-module validation showed that its average score was 3.15 indicating that it was feasible to implement within the study program.
\end{abstract}

Keywords Geometry Learning Subject, Inquiry-based E-module, Electronic Books, Elementary School Teacher Education Study Program

\section{Introduction}

The rapid development of information and communication technology in the globalization era has an impact on educational aspects [1]; one of which is a part of technology namely internet. In the context of learning, it is now easy to access learning materials online [2]. Thus, online learning enables students to learn anywhere [3] as long as there is stable internet connection [4]. Another advantage of online learning is the fact that online communication is repeatable. This means that students can repeat what they do not understand yet. One of the innovative online learning using Internet is e-book.

There have been several studies discussing e-book. One of which focused on how e-book turned out to be a resource of curriculum for independent learning either at school or at home [5]. E-book is also easily accessible since it has been used in cellular devices [3]. E-book as a form of digital book has positively impacted and contributed to the future development of digital books [6]. However, it is also at risk of piracy and virus attack [7] so that it is in need of protection from both. Based on related studies on the implementation of e-book, it is found that there needs to be innovations on electronic learning materials able to enhance students' self-independence and activity in e-modules.

E-modules are an independent learning material containing digital information [6]. They are also defined as electronic modules accessible through computers, laptops, tablets, and smartphones [5]. Some of the advantages of e-modules in comparison with printed ones are the presence of audios, videos, pictures, animations, and the existence of quizzes and feedbacks [1]. Furthermore, e-modules are a learning material with lessons, methods, limitations, and evaluation designed systematically to acquire desired competences based on relevant complexity levels [2].

Previous studies related to the development of modules using contextual approach showed that the main function of modules was as independent learning mediators so that students can learn based on their own speeds [8]. Modules are also believed to be able to create learning situations which are more well-planned, independent, complete, and with clear output [9]. Some of the important characteristics in developing a high quality e-module are (a) self-instruction; (b) self-contained; (c) stand alone; (d) adaptable; (e) user-friendly; (f) consistent; and (f) with clear organization (Suastika \& Wahyuningtyas, 2018; Suryawati et al., 2010). Therefore, it can be inferred that the development of inquiry-based e-module to enhance students' understanding in geometry is inevitable. 
Inquiry approach is a learning approach attempting to develop scientific way of thinking. This approach emphasizes independent learning and develops their creativity and problem solving skills [12]. In the process of teaching and learning, students are given an opportunity to find how to solve problems on their own using systematic way of thinking (Siagian and Nurfitriyani, 2012). Knowledge acquired through self-discovery is believed to last longer than that learned through the other ways [13].

Learning through discovery entirely enhances students' reasoning and free thinking skills [14]. To this relation, inquiry-based learning is relevant since it gives students problems to analyze and solve [15]. Inquiry approach enables students to solve problems, think critically, and learning independently using e-modules [16]. Activities on e-modules lead the students to find concepts and develop skills on learning geometry [17]. Considering the aforementioned reasons, this study aims to develop an inquiry-based e-module in Geometry Learning subjects. Geometry E-Module contains material to two-dimentional figure and geometry. In addition, the e-module was developed, containing independent activities that guide students to discover the concepts of two-dimentional figure and geometry constructions, so that they can be applied when teaching in primary schools.

\section{Methodology}

The focus of the study was to develop a product of learning materials in an e-module based on inquiry approach on Geometry Learning subject. The study was a development study adapting the three stages of Plompt comprising (1) preliminary research; (2) prototyping phases; and (3) assessment phases [18][19].

Figure 1 showed that there were three investigation stages to do including (1) preliminary research which meant analyzing learning materials to be presented, collecting learning resources, and analyzing students' experiences on learning geometry. At the preliminary research stage, researchers conducted observations at several universities to find out material studies and problems; (2) prototyping phases which included designing e-modules of geometry learning using inquiry approach as well as the research instruments. At the prototyping phase's stage, researchers create geometric e-modules with an inquiry approach that can be accessed by all students; and (3) assessment phases is validation of e-modules by material experts and practitioners. After the validation process, the e-module is revised according to the suggestions and input from the validator and adjusted to the geometry material

The subjects of the study were students of elementary school teacher education study program of Universitas Kanjuruhan Malang, Indonesia. The data were collected through e-module validation sheets, observation sheets, and learning outcome tests the data were then analyzed through (a) having feedbacks from validators for the qualitative data; and (b) the results of e-module validation and learning outcome tests for the quantitative data.

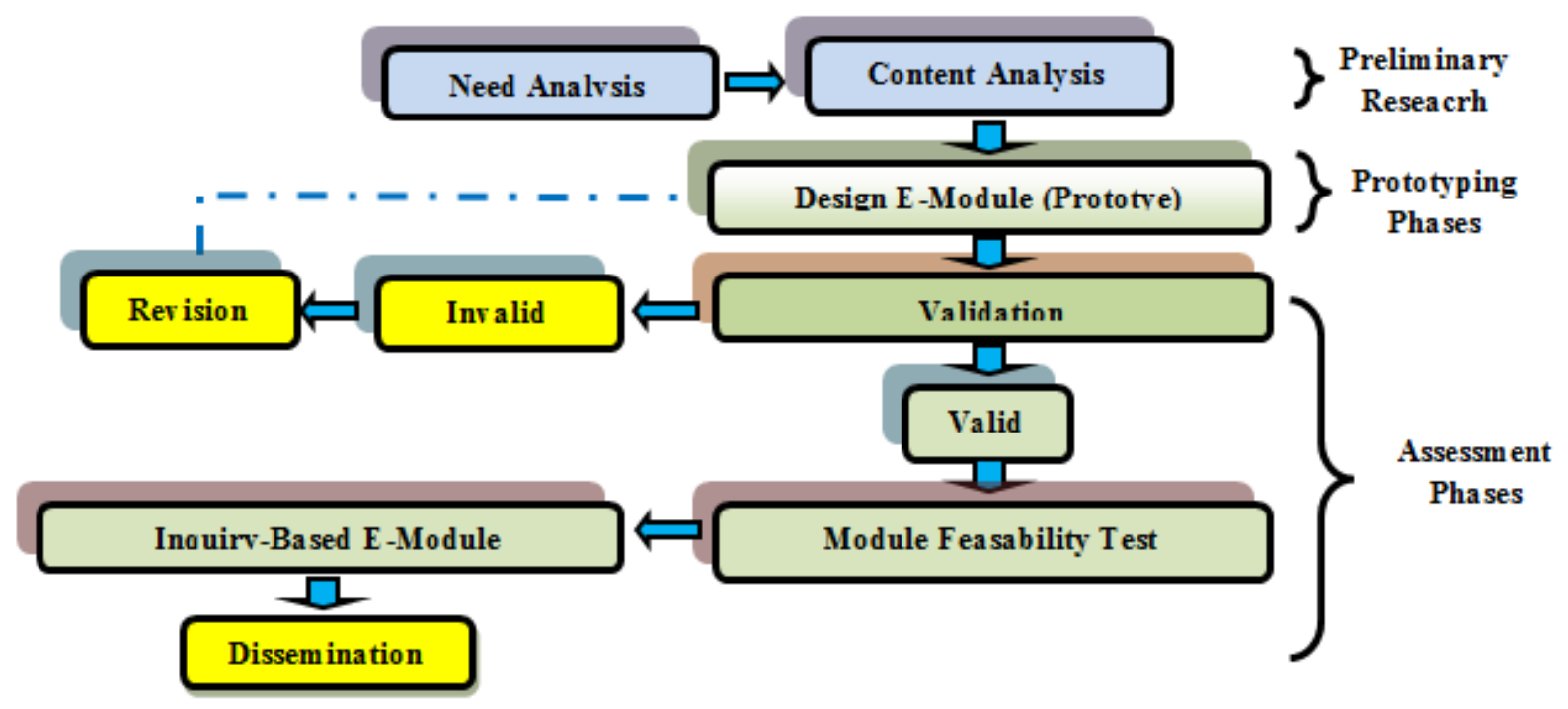

Figure 1. Procedure of Inquiry-Based E-Module Development 


\section{Inquiry-Based E-Module on Geometry Learning Subject Using Inquiry Learning Approach}

Learning activities had to focus on discovery; therefore, this study had the following steps of learning [16], [20].

\section{Problem identification}

The developed e-module put more focus on concept identification through activities on every session. On the module, there would be a simple problem to solve to strengthen the concepts they had in advance.

\section{Research}

Since the problems faced by the students were realistic, they were expected to read, understand, and find solutions to them.

\section{Analysis}

The students had problems in forms of questions leading to problem solving.

\section{Communication}

The module consisted of questions related to the previous lessons.

\section{Results and Discussion}

The results of the presentation of the inquiry-based module design on Geometry Learning emphasized on such three aspects as display, product engineering, and language. The display of the e-module was made as interesting as possible either in terms of layout, font, color selection, or pictures. Students had a tendency to use electronic learning resources rather than printed ones; this is due to the fact that electronic resources are able to show texts, pictures, animations, and interactive videos [1], [21]. In the meantime, the product engineering such as the application features, its usability, and accessibility run well and it is easily installed on laptops. This kind of easy access encourages users to continue learning the lessons on e-module [22]. Last but not least, language is important for understanding the content of the e-module. Communicative, non-ambiguous, and easy to understand language gives learners interest to read the module [5], [23]. Below is the display of the inquiry-based e-module on Geometry Learning subject:

Figure 2 showed the main display of the geometry e-module. On the initial stage, students had to register using their identity. Thus, they could login using the username and password made before.
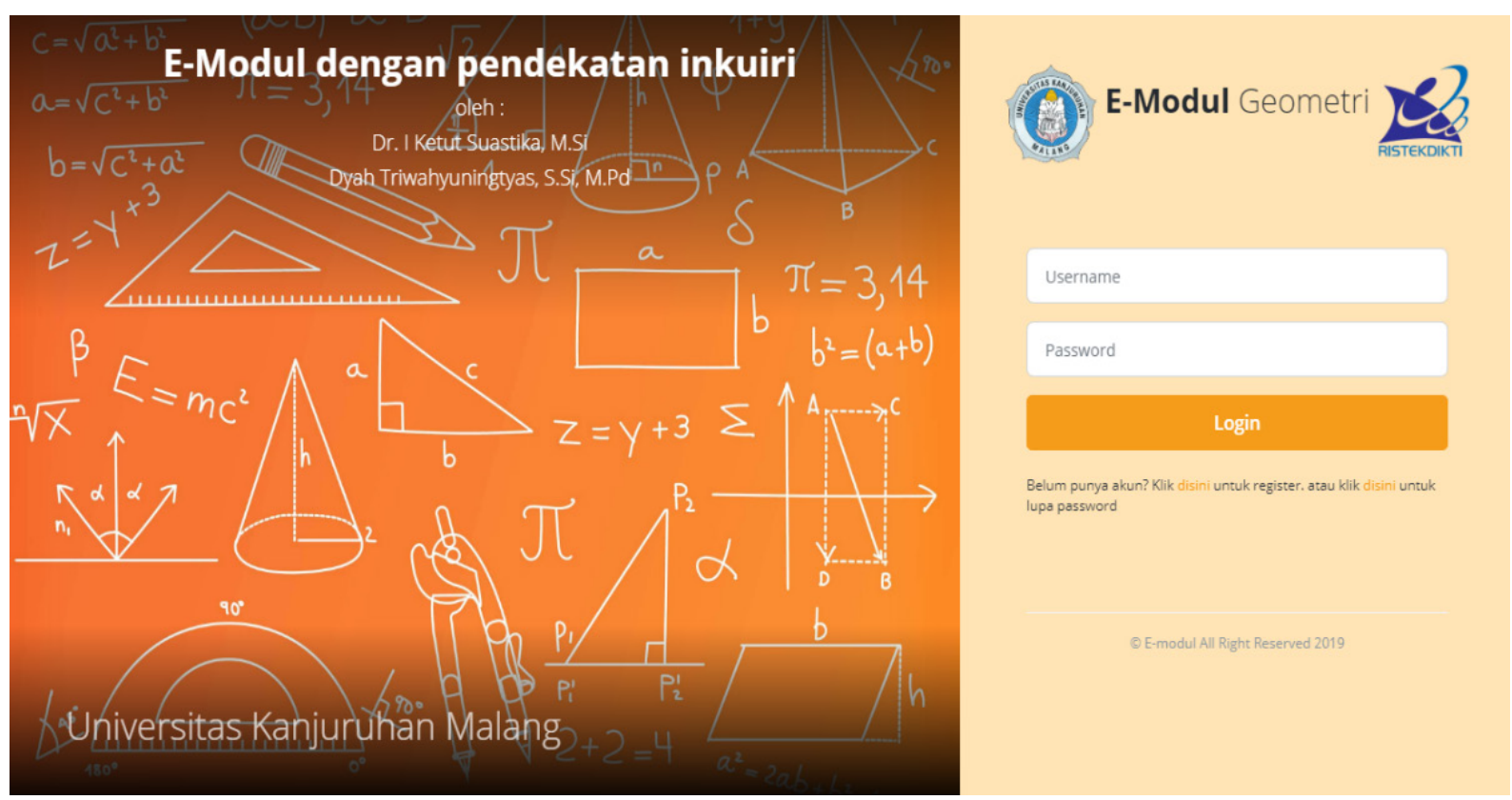

Figure 2. E-module main display 


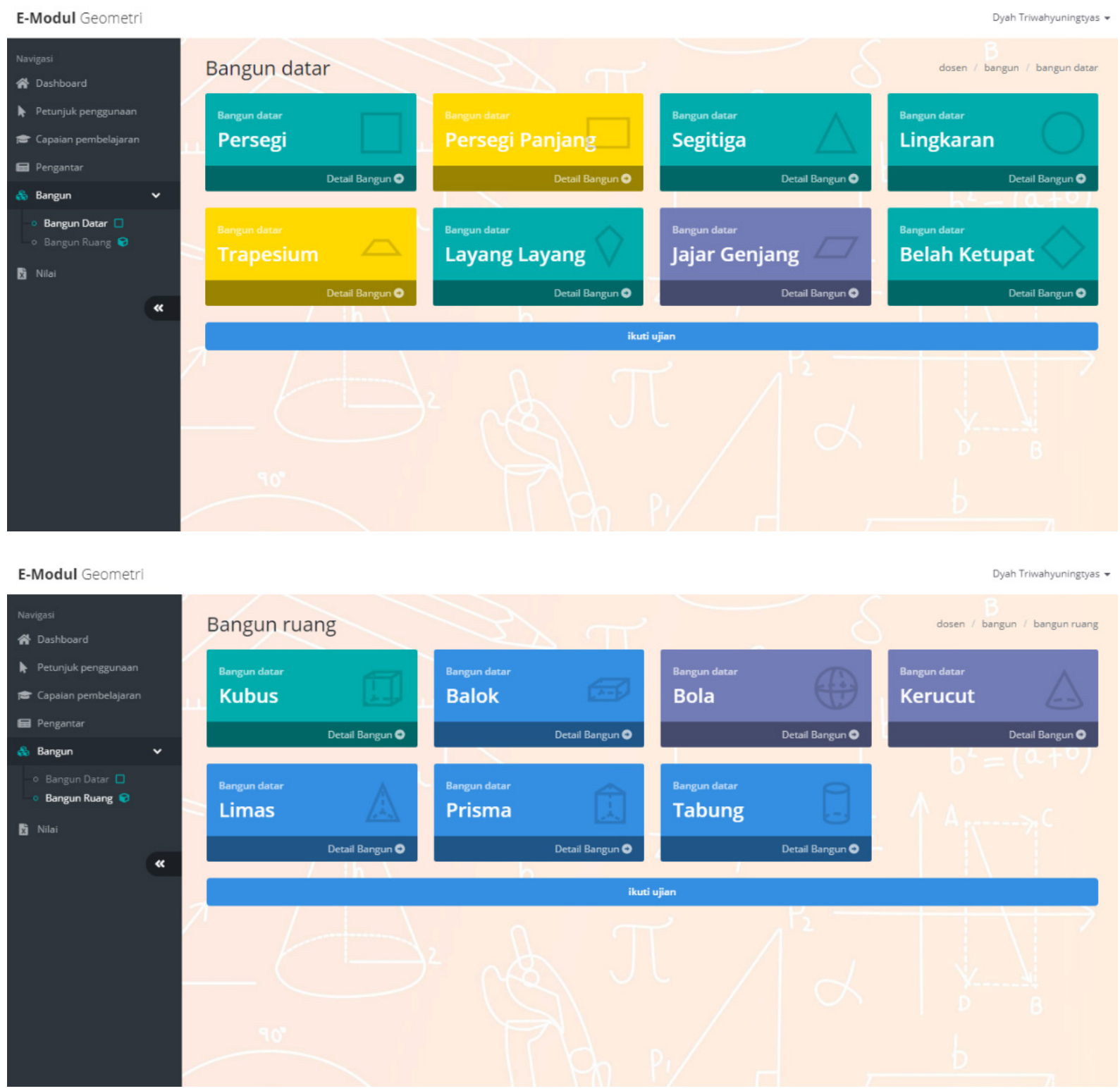

Figure 3. The display of geometry e-module content

Figure 3 shoed the content of the geometry e-module which contained (1) instructions; (2) learning outcome; (3) introduction; (4) figures and geometry; and (5) score. Instructions consist of how to learn the lessons on the e-module develop, how to the activities, how to conduct evaluation, and how to see the score after evaluation. Learning outcome contains the final desired output of the Geometry Learning subject. Introduction is all about the definition of base and axiom, and definitions related to two-dimensional figures and geometry which are the core of the lesson. Figures consist of (a) square; (b) rectangle; (c) triangle; (d) parallelogram; (e) rhombus; (f) kite; and (g) trapezium. In the meantime, geometry consists of (a) cube; (b) block; (c) prism; (d) tube; (e) cone; (f) pyramid; and (g) ball. Finally, score explains the score students get after evaluation. 
Soal 1

Sebuah segitiga samakaki memiliki panjang alas $10 \mathrm{~cm}$ dan tingginya $12 \mathrm{~cm}$. Berapa keliling dari segitiga samakaki tersebut?

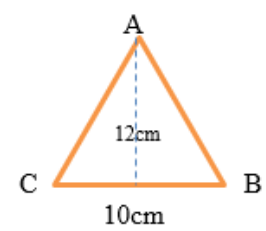

$27 \mathrm{~cm}$

$130 \mathrm{~cm}$

$36 \mathrm{~cm}$

$120 \mathrm{~cm}$

Jawab soal 1

Figure 4. The display of evaluation questions

Figure 4 showed the display of evaluation questions students need to take to measure their understanding on geometry. There are ten multiple-choice questions on two-dimensional figures and geometry. The results of the evaluation can be directly accessed by the students.

The learning activities on both two-dimensional figures and geometry on the e-module is based on inquiry approach. Thus, finding out the formula of the surface width and the volume should be in forms of activities. This aims to strengthen students' understanding on the formula [24]. Inquiry-based learning is strongly suggested since it is considered efficient to improve students' curiosity and motivation and able to develop their critical thinking skills [25].

The results of the e-module validation focus on three aspects covering (1) display; (2) product engineering; and (3) language as presented in Table 1.

Table 1. Validation Results

\begin{tabular}{|c|c|c|}
\hline No. & Validation focus & Average score \\
\hline 1 & Display & 3.33 \\
\hline 2 & Product engineering & 3.20 \\
\hline 3 & Language & 2.50 \\
\hline \multicolumn{2}{|c|}{ Average } & 3.15 \\
\hline
\end{tabular}

Based on table 1, it was found that the average of the validation results was 3.15 categorized into "very feasible" meaning that the e-module application can be implemented with revision. In terms of display, the layouting and the font used as well as the background are categorized into "very feasible" since the score was 4 . The same score also applies to the product engineering since the application is efficient to access and easily installed on laptops. Finally, the language on the application still needs revision; therefore, researchers gave several feedbacks in relation to language.

Based on the results of the "very feasible" e-module validation, in subsequent studies, e-module geometry will be tested on all PGSD students to find out the effectiveness of the e-modules that have been developed using the inquiry approach.

\section{Conclusions}

The inquiry-based geometry e-module has an advantage of easy access for elementary school teacher education study program students. This is reflected by the results of the feasibility tests of the e-modules in terms of three aspects covering content, display, product engineering, and language with an average score as high as 3.15 categorized as "feasible". Based on these results, the inquiry-based geometry e-module is feasible after several revisions from the validators. Furthermore, this type of e-module is in need of development in other discussions on Mathematics.

\section{Acknowledgements}

Kemenristek DIKTI is properly acknowledged for funding this study.

\section{REFERENCES}

[1] B. Lee, R. Fenoff, and S. Y. Paek, "Correlates of participation in e-book piracy on campus," J. Acad. Librariansh., vol. 45, no. 3, pp. 299-304, 2019.

[2] M. Letchumanan and R. Ahmad, "Utilization of e-book 
among University Mathematics Students," Procedia - Soc. Behav. Sci., vol. 8, no. 5, pp. 580-587, 2010.

[3] T. Chena, H. Weib, Y. Chengc, J. Leud, W. Shiha, and N. Hsua, "Integrating an e-book software with vector graphic technology on cloud platform," Procedia - Soc. Behav. Sci., vol. 176, pp. 1012-1019, 2015.

[4] R. A. Dore et al., "Early Childhood Research Quarterly The parent advantage in fostering children's e-book comprehension," Early Child. Res. Q., vol. 44, pp. 24-33, 2018.

[5] K. Roskos, J. Brueck, and L. Lenhart, "An analysis of e-book learning platforms: Affordances, architecture, functionality and analytics," Int. J. Child-Computer Interact., vol. 12, pp. 37-45, 2017.

[6] Y. K. Turel and S. Ozer Sanal, "The effects of an ARCS based e-book on student's achievement, motivation and anxiety," Comput. Educ., vol. 127, no. August, pp. 130-140, 2018.

[7] C. H. Jin, "Adoption of e-book among college students: The perspective of an integrated TAM," Comput. Human Behav., vol. 41, pp. 471-477, 2014.

[8] S. Wahyuningtyas, D. T. Yuniasih, N. Irawan, E. B; Susiswo, "Design Contextual Teaching and Learning Approach on Geometry Learning Module,” Pancar. Pendidik., vol. 6, no. 3, pp. 23-32, 2017.

[9] D. T. Wahyuningtyas and I. K. Suastika, "Developing Of Numbers Learning Module For Primary School Students By Contextual Teaching And Learning Approach," Pendidik. Dasar Indones., vol. 1, no. September, pp. 33-36, 2016.

[10] E. Suryawati, K. Osman, and T. S. M. Meerah, "The effectiveness of RANGKA contextual teaching and learning on student's problem solving skills and scientific attitude," Procedia - Soc. Behav. Sci., vol. 9, pp. 1717-1721, 2010.

[11] I. K. Suastika and D. Tri Wahyuningtyas, "Developing Module of Fractional Numbers using Contextual Teaching and Learning Approach," Pancar. Pendidik., vol. 7, no. 1, pp. 23-32, 2018.

[12] M. M. Alameddine and H. W. Ahwal, "Inquiry Based Teaching in Literature Classrooms," Procedia - Soc. Behav. Sci., vol. 232, no. April, pp. 332-337, 2016.

[13] C. Decker-lange, "Problem- and inquiry-based learning in alternative contexts: Using museums in management education,” Int. J. Manag. Educ., vol. 16, no. 3, pp. 446-459, 2018.

[14] M. Pedaste, M. Mäeots, L. A. Siiman, T. De Jong, Z. C. Zacharia, and E. Tsourlidaki, "Phases of inquiry-based learning: Definitions and the inquiry cycle," Educ. Res. Rev., vol. 14, pp. 47-61, 2015.

[15] D. Slavit and K. Lesseig, "The Development of Teacher Knowledge in Support of Student Mathematical Inquiry," Primus, vol. 27, no. 1, pp. 58-74, 2017.

[16] K. A. Brugar, "Inquiry by the Book: Using Children's Nonfiction as Mentor Texts for Inquiry," Soc. Stud., vol. 110, no. 4, pp. 155-160, 2019.
[17] P. Tan, R. Lambert, A. Padilla, and R. Wieman, "A disability studies in mathematics education review of intellectual disabilities: Directions for future inquiry and practice," J. Math. Behav, vol. 54, no. July, pp. 1-13, 2019.

[18] T. (SLO) Plomp and N. (SLO) Nieveen, "Educational Design Research Educational Design Research," Educ. Des. Res., pp. 1-206, 2013.

[19] M. N. Hudha, S. D. Aji, and C. Huda, "E-Rubric: Scientific Work Based on Android for Experimental Physic," IOP Conf. Ser. Mater. Sci. Eng., vol. 288, no. 1, 2018.

[20] Trianto, Mendesain Model Pembelajaran Inovatif-Progresif: Konsep, Landasan, dan Implementasinya Pada Kurikulum Tingkat Satuan Pendidikan. 2010.

[21] N. Imansari and I. Sunaryantiningsih, "Pengaruh Penggunaan E-Modul Interaktif Terhadap Hasil Belajar Mahasiswa pada Materi Kesehatan dan Keselamatan Kerja," VOLT J. Ilm. Pendidik. Tek. Elektro, vol. 2, no. 1, p. 11, 2017.

[22] M. Yalman, "Preservice teachers' views about E-book and their levels of use of E-books," Turkish Online J. Educ. Technol., vol. 13, no. 2, pp. 138-147, 2014.

[23] D. T. Wahyuningtyas, N. Yuniasih, and E. B. Irawan, "Two-Dimensional Figure E-Modul with Contextual Teaching and Learning ( CTL ) Approach,” Int. J. Eng. Technol., vol. 7, pp. 276-278, 2018.

[24] M. Voet and B. De Wever, "History teachers' conceptions of inquiry-based learning, beliefs about the nature of history, and their relation to the classroom context," Teach. Teach. Educ., vol. 55, pp. 57-67, 2016.

[25] Á. Suárez, M. Specht, F. Prinsen, M. Kalz, and S. Ternier, "A review of the types of mobile activities in mobile inquiry-based learning," Comput. Educ., vol. 118, pp. 38$55,2018$. 